\title{
PENANAMAN KEMANDIRIAN PADA ANAK DI SEKOLAH FIRST RABBIT PRESCHOOL AND DAY CARE
}

\author{
Syaifah Lisrayanti ${ }^{1}$; Fidesrinur $^{1}$ \\ ${ }^{1}$ Program Studi Pendidikan Guru Pendidikan Anak Usia Dini, Fakultas Psikologi dan Pendidikan, \\ Universitas Al Azhar Indonesia, Jalan Sisingamangaraja Kebayoran baru, Jakarta Selatan 12110 \\ Penulis untuk Korespondensi/ E-mail: fideza@uai.ac.id
}

\begin{abstract}
Abstrak - Hasil penelitian ditemukan bahwa peran guru dalam penanaman kemandirian anak usia 3-4 tahun disekolah first rabbit preschool and day care dapat tercapaimelaluiadanya peran guru yang telah dilaksanakan lewat kelima kontinum yang meliputi; 1) pengamatan; 2) pernyataan tidak langsung; 3) pertanyaan; 4) pernyataan langsung); dan 5) tindakan fisik. Contoh Kelima peran tersebut muncul di dalam rutinitas pada saat kedatangan dan penyambutan siswa hingga pelepasan siswa untuk pulang, yang disampaikan dan dijalankan dengan konsisten. Selanjutnya peran guru yang ada pada kesadaran diri terlihat dominan lebih besar dibandingkan tanggung jawab diri, motorik kasar dan perilaku prososial. Sementara itu hambatan yang di temukan dalam penanaman kemandirian anak berupa, permasalahan dalam diri anak sendiri yang berasal dari faktor internal yang meliputi hambatan dalam kesadaran diri dan tanggung jawab diri. Dapat disarankan dari hasil penelitian, untuk meningkatkan kemandirian baik disesuaikan dirumah maupun disekolah, agar pembentukan kemandirian sejalan.
\end{abstract}

Kata kunci: Kemandirian, Peran guru, Fisik dan Sosial Emosional

Abstract - The results of the study found that the role of teachers in instilling the independence of children aged 3-4 years at first rabbit preschool and day care can be achieved through the role of teachers who have been carried out through the five continuum which includes; 1) observation, 2) indirect statements, 3) questions, 4) direct statement, and 5) physical actions. The five roles appear in the routine on arrival and reception of students until the release of students to go home, which is delivered and carried out consistently. Furthermore, the role of the teacher in self-awareness appears to be greater than self responsibility, gross motor skills and prosocial behavior. Meanwhile the obstacles found in the cultivation of children's independence in the form of, problems within the children themselves are derived from internal factors which include obstacles in self-awareness and self responsibility. It can be suggested from the results of research, to increase independence whether adjusted at home or at school, so that the formation of independence in line.

Keywords: Independence, Teacher Role, Emotional Physical and Social

\section{PENDAHULUAN}

$\mathrm{P}$ usat Kurikulum Departemen Pendidikan Nasional (2007), seorang anak dapat dikatakan memiliki sikap kemandirian apabila anak mampu berinteraksi, mulai mematuhi aturan, dapat mengendalikan emosinya, menunjukkan rasa percaya diri, dan dapat menjaga diri sendiri. Perkembangannya dipengaruhi oleh berbagai stimulasi yang datang dari lingkungannya, selain potensi yang telah dimiliki sejak lahir sebagai keturunan dari orang tuanya. Sikap tersebut dapat dilihat ketika anak menjalani berbagai aktivitas maupun kegiatan sederhana baik di rumah maupun di sekolah. Sebagai contoh anak tidak lagi menangis ketika berpisah dengan orangtua atau pengasuhnya saat masuk sekolah.

Pentingnya menumbuhkan kemandirian sejak anak usia dini dikemukakan oleh Kartono dalam Fadholi (2011) bahwa potensi yang harus dikembangkan adalah kemandirian, karena pada usia prasekolah anak sudah mulai belajar memisahkan diri dari keluarga dan orangtuanya untuk memasuki suatu lingkungan yang lebih luas yaitu lingkungan taman kanak-kanak atau taman bermain. Kemandirian sangat penting 
dikembangkan pada anak sejak usia dini agar anak menjadi individu yang mampu melakukan kegiatan dengan kemampuan dirinya sendiri tanpa campur tangan dari orang lain. Untuk itu orangtua dan orang dewasa di sekitar anak harus memberikan bimbingan dan arahan kepada anak untuk mempersiapkan anak mengarungi kehidupan di masa yang akan datang.

Dodge (dalam Martinis, 2013) mengemukakan pendapat tentang kemandirian anak usia dini dapat dilihat dari pembiasaan perilaku dan kemampuan anak dalam fisik, percaya diri, bertanggung jawab, disiplin, pandai bergaul, mau berbagi, mengendalikan emosi. Hal tersebut sesuai dengan Tingkat pencapaian perkembangan anak usia 3 - 4 tahun bisa diukur melalui bagaimana anak bertingkah laku secara fisik. Selanjutnya Brewer (2007) juga menyatakan bahwa kemandirian anak taman kanak-kanak, indikatornya adalah pembiasaan yang terdiri dari kemampuan fisik, percaya diri, bertanggung jawab, disiplin, pandai bergaul, mau berbagi, mengendalikan emosi.

Kemandirian bisa berwujud pada perilaku fisik contohnya anak mampu melakukan toiletry yaitu pelatihan dalam melakukan toilet dengan upaya sendiri, guru memberi pemahaman kepada anak, seperti apakah anak ingin BAK (buang air kecil) dan BAB (buang air besar), dan nantinya guru hanya akan mengawasi. Namun, tidak hanya itu, kemandirian juga bisa berwujud pada perilaku sosial dan emosional, contohnya anak mau mengantri pada saat melakukan toilet training dengan sabar tanpa mendorong teman. Menurut Hidayat (2008) dampak dari kegagalan toilet training dapat menyebabkan anak menjadi kurang mandiri, memiliki sikap egois, keras kepala, cenderung ceroboh dalam melakukan kegiatan sehari-hari.

Kemandirian dapat diajarkan baik di rumah maupun di sekolah. Menanamkan kemandirian di rumah dapat dilakukan dengan cara, orang tua membiasakan anak memberikan tugas atau pekerjaan yang sederhana. Sebagai contoh merapihkan tempat tidur. Orang tua tidak selalu terus-menerus memanjakan anak dengan melakukan apa yang harusnya anak dapat lakukan sendiri, orang tua membiarkan anak melakukan apa yang harus anak lakukan. Orang tua selalu mengajarkan terlebih dahulu kepada anak guna untuk menumbuhkan kesadaran pada diri anak untuk tidak selalu bergantung.

Demikian sama halnya dengan menumbuh kembangkan kemandirian di sekolah, contohnya di First Rabbit Preschool and Day Care, guru memberikan motivasi pada anak untuk dapat melakukan kegiatan sederhana sendiri. Dengan memberikan contoh teladan, pengertian, penjelasan, mengawasi, membimbing anak-anak saat dalam kegiatan pembelajaran, serta semangat kepada anak dengan cara memberikan pengertian dan kesempatan kepada anak untuk melakukannya sendiri, serta mengatakan bahwa anak bisa melakukannya seperti teman-teman yang lainnya. Guru memberikan reward kepada anak sehingga mendorong anak untuk termotivasi lagi melakukan kegiatannya sendiri, seperti mampu makan bekal tanpa disuapi oleh guru kelas. Guru tidak selalu membantu anak-anak, guru memberikan tugas pada anak dalam menyelesaikan tugasnya, contohnya anak diajarkan memakai kedua pasang sepatu dan kaos kaki sendiri. Guru membiarkan anak menaruh dan mengambil tas pada tempatnya, anak juga dapat menaruh botol minumannya sendiri.

Di dalam Peraturan Menteri Pendidikan dan Kebudayaan (Permendikbud) No. 137 Tahun 2014 merupakan peraturan yang dikeluarkan oleh Menteri Pendidikan dan Kebudayaan tentang Standar Nasional Pendidikan Anak Usia Dini, Standar Tingkat Pencapaian Perkembangan Anak (STPPA) Paud Kurikulum 2013 Peraturan Menteri Pendidikan dan Kebudayaan. Membentuk kemandirian anak harus memperhatikan kedalam STPPA (Standar Tingkat Pencapaian Perkembangan Anak Usia 3-4 Tahun) Kurikulum 2013 dengan memilih metode, media, dan kegiatan yang sesuai dengan tingkat pencapaiannya.

Kemandirian terkait dengan kemampuan secara fisik dan kemampuan secara emosi sehingga dari banyaknya indikator yang terdapat pada aspek perkembangan fisik dan sosial emosional yang terdapat pada STPPA yang terkait dengan kemandirian adalah: Fisik motorik terdiri dari motorik kasar yaitu, 5) membersihkan kotoran (ingus), 6) menggosok gigi, 8) mengelap tangan dan muka sendiri. Sedangkan sosial emosional terdiri dari kesadaran diri yaitu, 1) mengikuti aktivitas dalam suatu kegiatan besar, 2) meniru 
apa yang dilakukan orang dewasa, 3) bereaksi terhadap hal-hal yang tidak benar (marah bila diganggu), 4) mengatakan perasaan secara verbal. Sedangkan tanggung jawab diri dan orang lain yaitu, 1) mulai bisa melakukan buang air kecil tanpa bantuan, 2) bersabar menunggu giliran, 3) mulai menunjukkan sikap toleran sehingga dapat bekerja dalam kelompok, 4) mulai menghargai orang lain, 5) mulai menunjukkan ekspresi menyesal ketika melakukan kesalahan. Juga perilaku prososial yaitu, 1) membangun kerjasama, 2) memahami adanya perbedaan perasaan (teman takut, saya tidak), 3) meminjam dan meminjamkan mainan.

Terkait dengan kemandirian yang ada di STPPA guru diharapkan memberikan stimulasi berupa mengeksplor bakat anak, dan diarahkan, dikuatkan bakatnya dan dilakukan pendekatan pada anak sesuai dengan minat bakatnya. Meskipun kemandirian merupakan hal yang penting dimiliki dan harus ditanamkan sejak dini pada anak namun kenyataanya anak-anak usia prasekolah masih mengalami kesulitan. Hal ini sesuai dengan hasil penelitian yang dilakukan oleh Indah Bayu Firdausa, Fakultas Psikologi Universitas Muhammadiyah Malang yang dilakukan pada tahun ajaran 2016/2017 yang berjudul "Analisis Faktor-Faktor Kemandirian Anak Usia Prasekolah (3-4 Tahun) yang di Titipkan di Tempat Penitipan Anak", diketahui bahwa tingkat kemandirian anak-anak tersebut masih rendah. Mereka masih kesulitan dalam menali tali sepatu, anak masih memerlukan bantuan dalam mengancingkan baju seperti saat kancing seragam anak lepas, maupun memakai kostum. Anak juga belum dapat makan sendiri dengan benar dan rapi.

Masalah yang sama terlihat di Sekolah TK Alazhar 17 Bintaro. Berdasarkan hasil observasi yang dilakukan pada tanggal 24 Oktober 2018 ditemukan pada kelompok toddler, dari 15 anak, 5 di antaranya belum menunjukkan perilaku mandiri. Hal ini terlihat pada saat anak memasang sepatu ketika kedatangan dan kepulangan masih memerlukan bantuan, selain itu anak juga meminta disuapi ketika pada waktu makan. Pada saat mencuci tangan masih memerlukan bantuan seperti menggunakan sabun cuci tangan dan ketika mengeringkan tangan dengan lap kering. Ketika anak melakukan BAK (buang air kecil), anak cenderung dibantu membuka dan memasangkan celana oleh guru kelas. Anak menangis saat ditinggalkan oleh orangtua dan pengasuhnya.

Terdapat lembaga pendidikan yang berhasil menerapkan kemandirian pada anak khususnya usia $3-4$ tahun, salah satunya adalah lembaga pendidikan First Rabbit Preschool and Day Care. Berdasarkan hasil observasi dan wawancara kelompok toddler 1 dan 2 pada Tanggal 28 Maret 2019 dan 9 April 2019, ditemukan dari kelompok toddler 1 dan 2 yaitu, 17 dari 20 anak mampu mengurus dirinya sendiri. Guru tidak selalu membantu anak contohnya terdapat pada saat anak BAK (buang air kecil) dan BAB (buang air besar), dalam pemasangan kaoskaki dan sepatu, makan dan membuka botol minum dengan upaya sendiri, mampu untuk lepas dari orangtua dan pengasuh pada saat kedatangan, menyeka air tumpah dengan menggunakan lap, menaruh kembali botol minuman pada tempatnya semula, dan mampu mengenali tas kepemilikannya, juga mampu mau berbagi pada orang baru sekalipun.

Kemandirian anak-anak yang terlihat tersebut tidak terlepas dari upaya yang dilakukan oleh guru, semua itu dikarenakan adanya pembiasaan serta peran guru dalam menanamkan kemandirian pada anak.

\section{Pengertian Kemandirian}

Kemandirian bagi anak-anak berbeda dengan kemandirian remaja ataupun orang dewasa. Jika mandiri untuk orang dewasa adalah kemampuan seseorang untuk bertanggung jawab atas apa yang dilakukan tanpa membebani juga merugikan orang lain, sedangkan mandiri bagi anak usia dini bukan berarti hidup sendiri.

Kemandirian yang dikemukakan Utomo (2005) sebagai salah satu komponen kepribadian yang mendorong anak untuk dapat mengarahkan dan mengatur perilakunya sendiri dan menyelesaikan masalah tanpa bantuan dari orang lain. Sama halnya dengan Kemandirian oleh Havighurst dalam Satmoko (2008) bahwa kemandirian adalah tindakan anak untuk mencoba memecahkan masalah yang dihadapi tanpa bantuan orang lain. Kemandirian bagi anak-anak tentunya tidak bisa disamakan dengan kemandirian remaja ataupun orang dewasa. Jika mandiri untuk orang dewasa adalah kemampuan seseorang untuk bertanggung jawab atas apa yang dilakukan 
tanpa membebani orang disekitarnya, maka mandiri bagi anak usia dini adalah mandiri enggan didampingi orang disekitarnya.

Bentuk kemandirian anak secara fisik adalah kemampuan untuk mengurus dirinya sendiri Nurfalah (2010). Contohnya anak usia 3-4 tahun yang sudah bisa menggunakan alat makan, seharusnya sudah bisa makan sendiri, mandi, berpakaian, buang air kecil dan buang air besar sendiri. Ketidak kemandirian fisik bisa berakibat pada anak yang selalu dibantu dan akan selalu tergantung pada orang lain karena marasa tidak memiliki kemampuan untuk mengurus dirinya sendiri. Akibatnya, ketika anak menghadapi masalah, ia akan mengharapkan bantuan orang lain untuk mengambil keputusan bagi dirinya dan memecahkan masalah, ditandai dengan mampu mengambil keputusan secara mandiri dan konsekuen terhadap keputusan tersebut, dan memiliki prinsip tentang benar dan salah, penting dan tidak penting.

Kemampuan sosial emosional anak dalam membentuk diri Menurut Mashar (2011) bahwa sebuah keterampilan anak dalam mengemukakan kesadaran, pengaturan, dan pengelolaan perasaan yang terjadi dalam dirinya lebih cepat berubah dalam memberikan tindakan melalui sikap diri untuk mencapai kebahagiaan dirinya sendiri. Contohnya pada orang dewasa saat ia merasa senang atau sedih sekalipun, bisa saja ia langsung mengemukakan secara verbal perasaannya. Namun berbeda dengan anak, anak tidak dapat dengan mudah mengemukakan perasaannya atau cenderung diam.

Diperkuat dengan mengutip sebuah artikel yang terkait tentang kemandirian oleh Megan Northrup, dalam Research Assistant yang disunting oleh Stephen F. Duncan, guru besar dari School of Family Life Birmingham Young University, menjelaskan:

"As children grow, they should be given more and more independence. At a youngage children can select the clothes they wear, food they eat, places to sit, and other small decision. Older children can have more of a say in choosing appropriate time to be at home, when and where to study, and which friends to associate with. The goal is to prepare children for the day they will leave their family and live without parental control".

Kutipan tersebut memiliki makna bahwa ketika anak-anak tumbuh, anak harus diberikan kebebasan. Seperti pada saat memilih pakaian yang mereka kenakan, makanan yang mereka makan, tempat duduk, dan keputusan kecil lainnya. Saat anak tumbuh besar maka anak di perbolehkan memilih kapan dan di mana belajar, dan memilih teman bergaul.

Kemandirian yang dikemukakan oleh Megan Northrup dalam articles teaching children self regulation dalam Research Assistant. Sedikitnya ada delapan unsur yang menyertai makna kemandirian bagi seorang anak yaitu, kemampuan untuk menentukan pilihan, berani memutuskan atas pilihannya sendiri, bertanggung jawab menerima konsekuensi yang menyertai pilihannya, percaya diri, mengarahkan diri, mengembangkan diri, menyesuaikan diri dengan lingkungannya, dan berani mengambil resiko atas pilihannya.

Anak dapat memilih keputusannya sendiri, setelah mampu menentukan pilihan maka anak bisa memutuskan pilihan tanpa campur tangan orang lain. Kemudian bertanggung jawab atas pilihannya, anak percaya akan dirinya sendiri bahwa ia mampu menghadapi tantangan yang di berikan walau sulit, anak dapat mengarahkan dirinya dengan mengetahui nila-nilai kebaikan. Dan juga dapat mengembangkan kemampuan yang di milikinya, serta mampu untuk bersosialisasi dengan teman sebaya dan berani akan resiko yang di hadapinya atas pilihan yang sudah di ambil.

\section{Ciri-ciri Kemandirian Anak}

Kemandirian akan mengantarkan anak memiliki kepercayaan diri dan motivasi intrinsik yang tinggi. Berikut adalah ciri-ciri kemandirian anak usia dini Wiyani (2014):

a. Memiliki kepercayaan kepada diri sendiri

b. Memiliki motivasi intrinsik yang tinggi.

c. Mampu dan berani menentukan pilihanya sendiri.

d. Kreatif dan inovatif

e. Bertanggung jawab menerima konsekuensi yang menyertai pilihanya.

f. Mampu menyesuaikan diri dengan lingkungannya.

g. Tidak bergantung pada orang lain 
Berdasarkan uraian di atas, ciri-ciri kemandirian anak usia dini adalah seorang anak yang memiliki rasa tanggung jawab dan kepercayaan diri, mampu dan mudah menyesuaikan diri dengan lingkungan, memiliki rasa ingin tahu yang tinggi dan selalu ingin mencoba sesuatu, tidak bergantung terus-menerus dengan orang dewasa, selalu berusaha untuk melakukan sendiri selagi anak mampu, serta memiliki motivasi untuk memilih maupun melakukan sesuatu yang anak inginkan.

\section{Kegiatan dalam Membentuk Kemandirian Anak}

Menurut Berk dalam Mangunsong (2006) bahwa kegiatan anak sehari-hari dalam bentuk kemandirian dapat dilihat dari:

a. Kemampuan anak dalam berpakaian.

b. Kemampuan anak dalam melakukan kegiatan makan

c. Kemampuan anak untuk mengurus diri ketika melakukan buang air

d. Mampu atau berani pergi sendiri

Sementara itu, menurut Nauta (2007) bentuk kemandirian anak dapat dilihat melalui kegiatan sehari-hari. yaitu: Kebersihan; Ketertiban; Kepemilikan; Kesabaran

Berdasarkan uraian di atas menjelaskan bahwa kegiatan anak sehari-hari dalam bentuk kemandirian dapat dilihat dari kemampuan anak dalam berpakaian, kemampuan anak dalam melakukan kegiatan makan, kemampuan anak untuk mengurus diri ketika melakukan buang air, dan mampu atau berani pergi sendiri Mangunsong (2006). Sedangkan menurut Nouta (2007) kegiatan anak sehari-hari dalam bentuk kemandirian dapat dilihat dari kemampuan anak dalam kebersihan, contohnya: seperti mengancingkan baju, memakai kaos kaki, dan melipat baju. Ketertiban, misalnya: membereskan mainan yang telah digunakan dan menaruhnya ditempat semula. Kepemilikan, contohnya anak meminta izin jika ingin meminjam mainan teman atau kakaknya. dan kesabaran, seperti anak mau berbaris sebelum masuk kelas tanpa menyelak teman didepannya.

Kemandirian adalah salah satu sikap yang terbagi menjadi dua yaitu, kemandirian fisik dan sosial emosional. Tindakan anak melalui sikap diri untuk mencoba memecahkan masalah yang dihadapi tanpa bantuan orang lain, dan dapat mengurus dirinya sendiri.

\section{Kemandirian Anak Usia 3-4 Tahun}

Menurut Wiyani (2013) kemandirian merupakan hal atau keadaan dapat berdiri sendiri dan merupakan karakter yang memungkinkan anak untuk tidak bergantung pada orang lain. Seperti sikap dan perilaku yang tidak mudah bergantung dengan orang lain dalam menyelesaikan tugas-tugasnya, juga sikap yang harus dibentuk oleh orang dewasa untuk membangun kepribadian anak.

Kemandirian yang ditanamkan sejak dini disekolah harus mengacu kepada STPPA (Standar Tingkat Pencapaian Perkembangan Anak Usia 3-4 Tahun). Terkait dengan kemampuan secara fisik dan kemampuan secara sosial emosinal sehingga indikator pada aspek perkembangan fisik dan sosial emosional yang terdapat pada STPPA yang terkait dengan kemandirian adalah:

Tabel 1. Standar Tingkat Pencapaian Perkembangan Anak Usia 3-4 Tahun

\begin{tabular}{|c|c|}
\hline Fisik & Sosial Emosional \\
\hline $\begin{array}{l}\text { Fisik motorik } \\
\text { terdiri dari } \\
\text { motorik kasar: } \\
\text { 1. membersihkan } \\
\text { kotoran } \\
\text { (ingus), } \\
\text { 2. menggosok } \\
\text { gigi, } \\
\text { 3. mengelap } \\
\text { tangan dan } \\
\text { muka sendiri. }\end{array}$ & $\begin{array}{l}\text { Sosial emosional terdiri dari } \\
\text { kesadaran diri: } \\
\text { a. mengikuti aktivitas dalam } \\
\text { suatu kegiatan besar, } \\
\text { b. meniru apa yang dilakukan } \\
\text { orang dewasa, } \\
\text { c. bereaksi terhadap hal-hal yang } \\
\text { tidak benar (marah bila } \\
\text { diganggu), } \\
\text { d. mengatakan perasaan secara } \\
\text { verbal. } \\
\text { Tanggung jawab diri dan orang } \\
\text { lain: } \\
\text { a. mulai bisa melakukan buang } \\
\text { air kecil tanpa bantuan, } \\
\text { b. bersabar menunggu giliran, } \\
\text { c. mulai menunjukkan sikap } \\
\text { toleran sehingga dapat } \\
\text { bekerja dalam kelompok, } \\
\text { d. mulai menghargai orang lain, } \\
\text { e. mulai menunjukkan ekspresi } \\
\text { menyesal ketika melakukan } \\
\text { kesalahan. } \\
\text { Perilaku prososial: } \\
\text { a. membangun kerjasama, } \\
\text { b. memahami adanya perbedaan } \\
\text { perasaan (teman takut, saya } \\
\text { tidak), }\end{array}$ \\
\hline
\end{tabular}




\begin{tabular}{|l|l|}
\hline & $\begin{array}{l}\text { c. meminjam dan } \\
\text { meminjamkan mainan. }\end{array}$ \\
\hline
\end{tabular}

\section{Peran Guru dalam Meningkatkan Kemandirian Anak}

Seorang pendidik akan selalu dituntut untuk memberikan yang terbaik bagi para pesertadidik. Tak terkecuali dalam hal bagaimana cara mereka berkomunikasi. Massardi (2012) menjelaskan bahwa bahasa merupakan sarana komunikasi dan ilmu. Dengan menggunakan bahasa Indonesia dengan baik dan benar, maka para pengajar dapat menghindarkan tindakan negatif "3M" (melarang, menyuruh, marah/ menghukum).

Komunikasi interpersonal para pengajar dengan para peserta didiknya secara baik dapat meningkatkan pengetahuan anak. Pontoh (2013) Memang pada hal tersebut, dapat mengingatkan kembali bagaimana pentingnya adanya komunikasi yang baik antara para pengajar dengan para peserta didiknya. Ada 5 jurus kontinum dan bahasa terstruktur dalam buku yang ditulis oleh Massardi (2012) yang dapat digunakan para pendidik pada anak-anak jenjang TK, PAUD, dan KB adalah sebagai berikut:

a. Visually Looking On

Guru melakukan pengamatan terhadap seluruh situasi yang terjadi di dalam sentra. Misalnya, pada saat seorang anak konflik dengan anak yang lain, maka jurus pijakan guru adalah melihat kedua anak itu secara dekat, sehingga mereka mengerti jika diperhatikan guru secara seksama.

b. Non Direct Statement

Pernyataan tidak langsung yang disampaikan guru kepada anak didiknya. Contoh bentuk kalimatnya adalah "sepertinya ada masalah di sini?".

c. Question

Berkomunikasi dengan anak menggunakan pertanyaan-pertanyaan langsung. Seperti "bagaimana seharusnya seorang anak berkomunikasi dengan temannya?".

d. Directive statement

Guru memberikan pernyataan langsung kepada anak didiknya yang misalnya saja sedang mengalami konflik "Anak yang sholeh adalah yang ketika berbicara menggunakan suara yang lembut dan katakata yang sopan".

e. Physical Intervention

Guru langsung melerai keduanya secara fisik dan memberi contoh bagaimana berkomunikasi dengan teman secara benar dan sopan.

Seorang pengajar sangat dianjurkan untuk tidak melakukan hal yang negatif, salah satunya adalah melakukan larangan terhadap para peserta didiknya Massardi (2012). Memberikan larangan, perintah merukan pemberian batasan bagi anak. Jika anak selalu diberikan batasan maka anak tidak akan memiliki kesempatan untuk menentukan arahnya sendiri, dan batasan batasan yang diberikan hanya akan membuat anak semakin lemah, bukan semakin kuat Gray (2006).

Dari beberapa jenis dan kontinum dalam komunikasi yang telah disebutkan di atas, komunikasi non direct merupakan salah satu jurus komunikasi yang tepat untuk digunakan berkomunikasi dengan anak-anak prasekolah. Karena dalam penerapannya komunikasi non direct sangatlah menghindari kata "tidak" yang dapat diartikan sebagai larangan (Joyce, 2007). Dengan menerapkan komunikasi non direct para pengajar dapat terhindar dari pemberian batasan pada anak. sehingga anak akan memiliki kesempata untuk terus mengembangkan kemampuan-kemampuan unik yang dimiliki anak.

Dengan menerapkan komunikasi non direct para pengajar akan terus dapat memberikan rangsangan pada anak. Dengan selalu memberikan rangsangan pada anak, anak akan mengembangkan suatu kesadaran diri dari tanggapannya terhadap dunia dan hubungannya dengan orang lain. Anak akan termotivasi sendiri untuk melihat, mendengar, merasakan, dan mengalami sesuatu yang ditawarkan oleh lingkungan sekitarnya Gray (2006). Rangsangan-rangsangan yang diterima oleh anak akan turut mengembangkan potensi yang anak miliki Prasetyono (2007).

Berbeda jika dalam berkomunikasi dengan anak, anak hanya diberikan instuksi, larangan, dan peraturan-peraturan yang tidak sesuai dengan keinginan dan kebutuhan anak anak akan menjadi lemah, menurunkan kreativitas anak, daya imajinasi anak akan terbatasi, anak 
tidak akan mempunyai kesempatan untuk mendaptkan apa yang anak inginkan, anak tidak dapat mengeksplor ide-ide unik yang mereka miliki. dan tentunya batasan-batasan yang diberikan pada anak tersebut hanya akan membuat anak mematikan segala kemampuan yang anak miliki, dan tidak dapat mengembangkannya Severe (2002).

\section{Peran Guru dalam Penanaman Kemandirian}

\section{a. Penanaman Kemandirian}

Dijelaskan Shalihah (2010) bahwa peran pendidik dalam menanamkan kemandirian pada anak sangat penting. Pendidik berperan dalam memberi motivasi, dorongan, arahan, bimbingan, nasihat, serta petunjuk jika diperlukan. Shalihah (2010) juga menuliskan bahwa terdapat beberapa hal yang dapat dilakukan untuk menanamkan kemandirian pada anak, membuatnya tidak suka bergantung dan dapat mengambil keputusan sendiri. Memberi kesempatan anak belajar memilih, bantuan bisa diberikan sebagai alternatif. Anak lebih terlatih untuk membuat keputusan jika terbiasa dihadapkan dengan beberapa pilihan, terbiasa menentukan pilihan secara sederhana maka akan memudahkan anak untuk menentukan keputusan dalam kehidupan seharihari, pendidik dapat berperan untuk membimbing anak menuju pada pilihan sebagai alternatif pemecahan masalah yang dihadapi anak.

Pendidik harus menghargai hasil kerja anak dan sabar pada prosesnya (Shalihah, 2010). Ketika anak melakukan sesuatu pendidik harus bersabar menunggu proses yang dijalani anak dengan tidak terburu-buru memberikan bantuan. Hasil kerja anak harus dihargai walaupun itu tidak memuaskan dan tidak sesuai dengan yang diharapkan. Kemudian ia juga mengatakan jangan banyak bertanya hanya karena ingin dianggap perhatian. Pendidik menanyakan hal-hal yang wajar kepada anak karena jika bertanya secara berlebihan anak akan berpikir itu bukan bentuk perhatian. Selanjutnya menanamkan kemandirian pada anak usia dini menurut Novita (2007) ada 3 hal yang harus diperhatikan guru, yaitu: Sabar; Aktivitas beragam; serta Tak banyak kritik

Berdasarkan pendapat di atas kemandirian sebaiknya diajarkan pada anak sedini mungkin sesuai dengan perkembangan kemampuan anak juga tahapan usia anak. Dalam mengajarkan kemandirian bagi anak usia dini, ada beberapa hal yang harus diperhatikan oleh guru, yaitu kesabaran, aktivitas beragam, dan tidak banyak mengkritik.

\section{b. Pengelolaan Kelas}

Henley dalam Emmer (2001) menyatakan bahwa pengelolaan atau manajemen kelas adalah kemampuan mengajar yang penting bagi guru, karena dapat mengurangi gangguan di dalam kelas dan menciptakan lingkungan belajar untuk mendukung perkembangan intelektual dan emosional anak. Di samping itu, Smith (2012) juga menekankan pentingnya pemberian konsekuensi perilaku. Bila siswa tidak meresponnya, maka guru dapat mengambil tindakan, contohnya seperti hukuman. Selanjutnya Smith (2012) menemukan bahwa rutinitas dan aturan akan lebih dapat dipatuhi anak bila diajarkan secara implisit. Artinya, guru melibatkan anak dalam interaksi yang dapat dilakukan dengan menggunakan contoh-contoh atau menggunakan pertanyaan dalam mengajarkan rutinitas dan aturan.

\section{c. Peraturan (Rules)}

Peraturan adalah identifikasi dan ekspektasi umum dan perilaku yang mencangkup berbagai situasi Dixie (2007). Peraturan dapat dikembangkan dengan mendefinisikan perilaku yang tidak dapat diterima anak akan diam ketika berbicara, setelah guru berbicara memberikan instruksi. Peraturan membantu anak-anak belajar perilaku yang diperlukan untuk bekerja sama dengan orang lain. Peraturan akan membuat anak-anak belajar disiplin.

Peraturan dipelajari melalui peraturan tertulis dan contoh secara terus-menerus sehingga mendapatkan tanggapan yang tepat dan pantas untuk sebuah peraturan. Agar peraturan menjadi lebih efektif, peraturan harus jelas dan diberlakukan secara adil dan konsisten. Rink (2010), menunjukkan bahwa guru dapat mengikuti panduan berikut dalam mempersiapkan peraturan:

1) Rules should be developcooperatively with students when possible (peraturan harus dikembangkan secara kooperatif dengan siswa bila memungkinkan). 
2) Rule should be communicated in language that is age appropriate (peraturan harus dikomunikasikan dalam bahasa yang sesuai dengan usia).

3) Rules should be few (four to seven) so student will remember them (peraturan haruslah sedikit (4-7) sehingga siswa akan mengingatnya).

4) State rules positively and provide both positive and negative example (dimulai dengan peraturan secara positif dan memberi contoh dari keduanya baik positif dan negatif).

5) Rules must be consistent with school rules (peraturan harus konsisten dengan peraturan sekolah).

6) Develop the consequences and clearly identify their relationship to rules violations (mengembangkan konsekuensinya dan secara jelas mengidentifikasi hubungan mereka dengan pelanggaran peraturan).

7) Reinforce the rules consistently and fairly (memperkuat peraturan secara konsisten dan adil).

8) Make sure that the student understandthe rules (pastikan siswa memahami peraturan).

Berdasarkan pemahaman di atas maka, peraturan harusnya dikembangkan secara kooperatif dengan siswa bila memungkinkan, juga harus dikomunikasikan dalam bahasa yang sesuai dengan usia anak. Kemudianperaturan haruslah sedikit sehingga siswa akan mudah dalam mengingatnya. Misalnya dimulai dengan peraturan secara positif seperti memberi contoh yang positif maupun berupa contoh yang negatif. Peraturan harus dibuat konsisten dalam mengembangkan konsekuensi juga harus secara jelas mengidentifikasi hubungan dengan pelanggaran peraturan. Misalnya memperkuat peraturan secara konsisten dan juga adil serta pastikan anak memahami peraturan yang telah dibuat.

\section{d. Rutinitas atau Prosedur}

Menurut Rink (2006) Rutinitas adalah prosedur kegiatan yang dilakukan didalam maupun diluar kelas, perilaku yang cenderung diulangi, terstruktur, kecuali berpotensi dapat menggangu proses pembelajaran. Rutinitas sering disebut prosedur, mendeskripsikan bagaimana berbagai kegiatan dilaksanakan dikelas, prosedur adalah cara untuk menyelesaikan berbagai hal dikelas. Seperti disebutkan, rutinitas yaitu prosedur untuk menyelesaikan tugas atau tugas-tugas khusus dalam kelas. Dalam hal ini rutinitas atau prosedur biasanya mengacu pada kegiatankegiatan khusus dan mereka biasanya ditunjukkan untuk menyelesaikan tugas- tugas dari pada melarang perilaku (Apley, 2001).

Kunci untuk mengajar rutinitas secara efektif tidak berbeda dengan kunci untuk mengajarkan keterampilan olahraga. Menurut Siedentop \& Tannehil (2000) strategi mengajar dalam menentukan rutinitas, yaitu:

a. Menjelaskan dan menunjukkan, menjelaskan prosedur dalam bahasa yang usia tertentu, dan menunjukkan siswa yang terlihat. Tampilkan dengan contoh, menunjukkan cara yang salah untuk melakukan sesuatu selain menunjukkan dengan cara yang benar.

b. Berlatih, memberikan kesempatan untuk berlatih rutinitas atau prosedur.

c. Mengharapkan kesempurnaan, arah reward. Mengharapkan kesempurnaan dan dukungan anak-anak karena mereka secara bertahap menjadi lebih baik dan lebih baik.

d. Gunakan model yang positif, ketika anak atau kelompok berhasil melakukan prosedur, tunjukkan keseluruh kelas.

e. Memberikan umpan balik, memperkuat keberhasilan dan peningkatan dan memberikan umpan balik perilaku khusus dari pada umpan balik.

f. Gunakan kegiatan untuk berlatih rutinitas, gunakan beberapa kegiatan yang memungkinkan anak-anak untuk berlatih rutinitas tertentu.

g. Periksa pemahaman anak-anak. Minta mereka untuk menjelaskan prosedur dan mengapa penting untuk melakukkannya dengan benar. Jadi rutinitas harus diajarkan untuk semua aspek prosedural dari pelajaran.

Berdasarkan latar belakang yang telah dipaparkan di atas, maka perlu dilakukan penelitian untuk mengetahui bagaimana Peran Guru dalam Penanaman Kemandirian Pada Anak Usia 3-4 Tahun di Sekolah First Rabbit Preschool and Day Care.

\section{METODE PENELITIAN}

Penelitian ini dilakukan di First Rabbit Preschool and Day Care yang beralamat di jalan raya R.C Veteran Komplek Pekerjaan 
Umum (PU) No. B2 Veteran Bintaro Jakarta Selatan, DKI Jakarta.

Adapun yang menjadi alasan dipilihnya subjek penelitian ini, dikarenakan anak-anak kelompok toddler 1 dan toddler 2 dapat terlihat kemandiriannya khususnya di usia 3-4 tahun. Kelompok toddler 1 yaitu berjumlah 9 orang anak dan toddler 2 berjumlahkan 11 orang anak yang terdapat di First Rabbit Preschool and Day Care. Adapun tenaga pendidik yang menjadi subjek penelitian ialah 1 (satu) kepala TK, 1 (satu) orang guru yang berada di kelompok toddler 1 dan 1 (satu) orang guru yang berada ditoddler 2 .

Penelitian ini menggunakan metode penelitian kualitatif deskriptif yang bertujuan memberikan gambaran secara terperinci mengenai suatu gejala sosial tertentu, yaitu untuk mendapatkan suatu gambaran mengenai Peran Guru dalam Penanaman Kemandirian Pada Anak Usia 3-4 Tahun di Sekolah First Rabbit Preschool and Day Care.

Teknik pengumpulan data yang digunakan di dalam penelitian di sekolah First Rabbit Preschool and Day Care menggunakan teknik observasi; Wawancara; dan Dokumentasi. Dan Tenik Analisis Data yaitu data reduction data (reduksi data), data display (penyajian data), dan conclusion drawing/verification (penarikan kesimpulan/ verifikasi).

Adapun jenis triangulasi yang dipilih dalam penelitian ini adalah triangulasi teknik dan triangulasi sumber. Jenis triangulasi ini menghimpun data dari hasil, seperti mengecek data dapat melalui wawancara, observasi, dan dokumentasi. Selanjutnya dilakukan pengecekan terhadap kesesuaian dari ketiganya, yaitu kesesuaian lebih lanjut kepada sumber data yang bersangkutan untuk memastikan data mana yang dianggap benar. dilakukan dengan cara mengecek data yang telah diperoleh melalui beberapa sumber, kemudian data yang diperoleh dianalisis oleh peneliti sehingga menghasilkan suatu kesimpulan.

\section{HASIL DAN PEMBAHASAN}

\section{Peran Guru}

Kemandirian bagi anak-anak tentunya tidak bisa disamakan dengan kemandirian remaja ataupun orang dewasa. Jika mandiri untuk orang dewasa adalah kemampuan seseorang untuk bertanggung jawab atas apa yang dilakukan tanpa membebani orang disekitarnya, maka mandiri bagi anak usia dini adalah mandiri enggan didampingi orang disekitarnya.

Aspek kemandirian yang ditanamkan sejak dini disekolah harus mengacu kepada STPPA (Standar Tingkat Pencapaian Perkembangan Anak Usia 3-4 Tahun). Terkait dengan kemampuan secara fisik dan kemampuan secara sosial emosinal sehingga indikator pada aspek perkembangan fisik dan sosial emosional yang terdapat pada STPPA yang terkait dengan kemandirian meliputi; kesadaran diri, tanggung jawab diri dan perilaku prososial, pada aspek fisik meliputi fisik yaitu motorik kasar.

Terkait dengan peran guru ada 5 jurus kontinum dan bahasa terstruktur yang bisa dijadikan acuan dalam buku yang ditulis oleh Massardi (2012) yang dapat digunakan para pendidik pada anak-anak jenjang TK, PAUD, dan KB meliputi:Visually Looking On (pengamatan), Non Direct Statement (pernyataan tidak langsung), Question (pertanyaan), Directive statement (pernyataan langsung), Physical Intervention (tindakan fisik).

\section{Kesadaran Diri}

Aspek kemandirian yaitu sosial emosional di dalam kesadaran diri yang terdapat dalam kegiatan yaitu meniru apa yang dilakukan orang dewasa. Berkaitan dengan kesadaran diri yaitu yang terdapat pada rutinitas kedatangan dan penyambutan siswa. Sedangkan peran guru yang terdapat yaitu ada pada pengamatan dan tindakan fisik, Anak memperhatikan tingkah laku antara guru dan orangtua, sebagai mana pengamatan berikut: Yaitu guru miss LC dan miss SI juga orang tua bersalaman kemudian anak R mengamati tingkah laku antara guru dan orang tua (6/11/2019: 08:30). Sedangkan pada saat tindakan fisik, yaitu guru mengajarkan anak untuk bersalaman dengan guru kelas dan guru asisten, seperti: Miss LC dan miss SI memberikan tangan untuk anak sambut menyalami guru (6/11/2019: 08:30).

Sementara itu mengatakan perasaan secara verbal, dimana di dalam rutinitas terdapat kedatangan dan penyambutan siswa, guru berperan dalam pertanyaan, dan pernyataan langsung. Melalui guru bertanya kepada anak didik: Guru yaitu miss LC dan miss SI bertanya kepada anak A apakah sudah sarapan dirumah? 
dan anak A menjawab sudah (6/11/2019: 08:30). Sementara pernyataan langsung, guru mengucapkan sapaan kepada anak: Miss LC dan miss SI mengucapkan sapaan pagi kepada anak A dan anak A menjawab sapaan guru, (6/11/2019: 08:30).

Sementara itu mengikuti aktivitas dalam suatu kegiatan besar, dimana di dalam rutinitas terdapat playground time sesuai dengan peran guru yang meliputi pernyataan tidak langsung, pertanyaan dan pernyataan langsung dan juga tindakan fisik. Pada saat bermain mainan mobil-mobilan terlihat anak-anak saling dorong satu sama lain. Untuk itu guru mengingatkan dengan menggunakan pernyataan tidak langsung: Miss LC dan miss SI mengingatkan $\mathrm{R}$, "bermain tidak baik jika saling mendorong teman" (6/11/2019: 08.45).

Sementara itu pertanyaan, pada saat anak menangis karena ada anak lain yang mengganggu sebagai berikut: Miss LC dan Miss SI bertanya:"ada masalah apa yang membuat anak menangis?" dan R menjawab "bahwa ada yang mengganggunya" (6/11/2019: 08:45). Sedangkan pada pernyataan langsung miss LC dan miss SI memberikan pernyataan langsung kepada R dan I sebagai berikut: Miss LC dan miss SI berkata bahwa, "anak yang baik adalah saat saling menyayangi" (6/11/2019: 08:45)

Selanjutnya pada saat tindakan fisik yaitu guru merangkul anak untuk saling bermaafan, sebagai berikut: Guru yaitu miss LC dan miss SI merangkul kedua anak yaitu $\mathrm{R}$ dan I untuk saling bermaafan dengan bersalaman dan anak yaitu $\mathrm{R}$ dan I: saling menyambut tangan teman untuk bermaafan (6/11/2019: 08:45). Bereaksi terhadap hal-hal yang tidak benar (marah bila diganggu), dimana didalam rutinitas terdapat playground time sesuai dengan peran guru yang meliputi pertanyaan, pernyataan langsung, dan tindakan fisik. Pertanyaan terjadinya pertengkaran kepada kedua anak, maka guru bertanya ada masalah apa kepada anak: Guru kelas dan guru asisten yaitu miss LC dan miss SI bertanya kepada anak: "ada masalah apa yang membuat anak bertengkar?" dan anak yaitu $\mathrm{R}$ menjawab bahwa ada yang mengganggunya, (6/11/2019: 08:45)

Pada pernyataan langsung guru memberikan nasihat kepada anak: Guru berkata: "bahwa anak yang baik adalah yang mau bergantian mainan dengan temannya" (6/11/2019: 08:45). Saat tindakan fisik guru mencoba mengajak anak untuk saling berjabat tangan: Miss LC dan miss SI merangkul kedua anak untuk berpegangan tangan berjanji akan meminjamkan mainan satu sama lain. $\mathrm{R}$ dan $\mathrm{I}$ : saling menyambut tangan teman $(6 / 11 / 2019$ : 08:45).

Mengikuti suatu aktivitas dalam suatu kegiatan besar, dimana di dalam rutinitas terdapat masuk kelas sesuai dengan peran guru yang meliputi pertanyaan, pernyataan langsung, dan tindakan fisik. Pada saat pengamatan seperti halnya: Guru kelas kelompok toddler 1 bernama miss UM beliau di damping asisten kelas yaitu miss TR mengamati anak yang belum membuat barisan yaitu M (28/3/19: 09.00). Kemudian dalam pernyataan tidak langsung guru kelas dan guru asisten mengajak anak-anak untuk berkumpul membuat barisan: Miss UM beliau di damping asisten kelas yaitu miss TR mengajak anak-anak untuk berkumpul membuat barisan kereta menuju kelas (28/3/19: 09.00).

Selanjutnya pada tindakan fisik terdapat aktivitas sebagai berikut: Guru yaitu miss UM dan miss TR berkata pada semua anak untuk saling memegang bahu teman didepannya dan anak saling memegang bahu teman didepannya (28/3/19: 09.00). Meniru apa yang dilakukan orang dewasa, dimana di dalam rutinitas terdapat masuk kelas sesuai dengan peran guru yang meliputi pernyataan langsung dan tindakan fisik.Pernyataan langsung guru melakukan kegiatan bernyanyi dengan anak dalam hal sebagai berikut: Guru miss UM dan miss TR bernyanyi lagu kereta api dan anakanak kelas toddler 1 meniru guru bernyanyi lagu kereta api (28/3/19: 09.00).

Tindakan fisik yaitu berupa guru memberikan contoh aktivitas pada gerak tangan anak didik seperti: Miss UM dan miss TR mencontohkan anak meletakkan sepatu pada raknya dan anak menaruh sepatu pada tempatnya (28/3/19: 09.00). Mengatakan perasaan secara verbal, dimana di dalam rutinitas terdapat circle time sesuai dengan peran guru yang meliputipengamatan. Yang dilakukan dalam pengamatan berikut: Miss UM dan miss SI memberikan intruksi agar anak maju ke depan satu persatu yaitu anak toddler 1 dan 2 menyimak guruanak A dan H (9/4/19: 09.30). 
Meniru apa yang dilakukan orang dewasa, dimana didalam rutinitas terdapat circle time sesuai dengan peran guru yang meliputi tindakan fisik. Tindakan fisik meliputi gerakan seperti hal di bawah ini: Guru miss UM dan miss SI memperagakan gerak diawal agar anak A dan Ha dari toddler 1 dan 2 (maju kedepan kelas untuk memperagakan gerakan menggunakan gerak pada (9/4/19: 09.30).

Mengatakan perasaan secara verbal, dimana didalam rutinitas terdapat circle time sesuai dengan peran guru yang meliputi pernyataan langsung dalam hal ini anak-anakakan menyebutkan secara langsung kostum yang mereka kenakan, berikut di bawah: Guru miss UM dan miss SI menyiapkan anak untuk tampil percaya diri di depan orangtua nanti, A dan $\mathrm{H}$ dari toddler 1 dan 2 menyebutkan peragaan busana apa yang dikenakan dari daerah asal (9/4/19: 09.30).

Mengikuti suatu aktivitas dalam suatu kegiatan besar, dimana di dalam rutinitas terdapat psikomotor time sesuai dengan peran guru yang meliputipernyataan tidak langsung dan pernyataan langsung. Pernyataan tidak langsung, seperti ucapan secaratidak langsung yang dikatakan guru kepada anak, seperti halnya kalimat ini: Miss UM beliau di damping asisten kelas yaitu miss TR mengajak anak K untuk berbaris sebelum melakukan toiletry dan anak berbaris didepan kamar mandi (28/3/19: 10.00).

Pernyataan langsung yang mengacu pada pernyataan yang disampaikan oleh guru kepada anak didik, perihal: Guru miss UM beliau di damping asisten kelas yaitu miss TR mencontohkan kepada anak untuk menggulung lengan baju agar tidak basah dan anak $\mathrm{K}$ menggulung lengan baju sendiri (28/3/19: 10.00). Meniru apa yang dilakukan orang dewasa, dimana di dalam rutinitas terdapat psikomotor time sesuai dengan peran guru yang meliputi pernyataan tidak langsung. Pernyataan tidak langsung sendiri seperti: Guru yaitu miss UM dan miss TR memberitahu anak untuk mengantri pada saat berbaris memasuki kamar mandi dan anak A dan Utoddler 1 memberitahu temannya untuk tidak menyelak (28/3/19: 10.00).

Mengikuti aktivitas dalam suatu kegiatan besar, dimana didalam rutinitas terdapat snack time dengan peran guru yang meiliputi tindakan fisik yang berupa: Guru miss UM dan miss SI mengingatkan untuk menunggu temannya anak A dan Ha dari toddler 1 dan 2 bersiap membuka bekal makanan dan minuman menunggu semua temannya untuk berkumpul makan bersama (9/4/19: 10.30).

Meniru apa yang dilakukan orang dewasa, dimana didalam rutinitas terdapat snack time sesuai dengan peran guru yang meliputi tindakan fisik yang berarti: Guru miss UM dari toddler 1 dan miss SI dari toddler 2 mengingatkan anak $\mathrm{C}$ dan $\mathrm{M}$ untuk berdoa mengangkat tangan dan anakberdoa dengan mengangkat kedua tangan (9/4/19: 10.30). Mengatakan perasaan secara verbal, dimana didalam rutinitas terdapat snack time sesuai dengan peran guru yang meiliputi pernyataan langsung, demikian halnya tertera: Guru yaitu miss UM dari toddler 1 dan miss SI dari toddler 2 memimpin doa bersama anak-anak dan semua berdoa saat sebelum makan (9/4/19: 10.30).

Mengikuti aktivitas dalam suatu kegiatan besar, dimana didalam rutinitas terdapat pelepasan siswa untuk pulang sesuai dengan peran guru yang meiliputi pernyataan tidak langsung, sesuai dengan yang ada dibawah: Miss UM dari toddler 1 dan miss SI dari toddler 2 menyuruh anak-anak untuk menunggu sampai dijemput semuanya menunggu jemputan (9/4/19: 11.00).

Dari uraian di atas dapat terlihat, bahwa aspek sosial emosional yang terdiri dalam kesadaran diri, yang meliputi mengikuti aktivitas dalam suatu kegiatan besar, yaitu hambatan yang terjadi dapat terlihat di pernyataan tidak langsung, pertanyaan, pernyataan langsung, dan tindakan fisik. Selanjutnya meliputi bereaksi terhadap hal-hal yang tidak benar (marah bila diganggu), yaitu hambatan yang terjadi dapat terlihat di pertanyaan, pernyataan langsung, dan tindakan fisik. Kemudian meliputi mengikuti aktivitas dalam suatu kegiatan besar, yaitu hambatan yang terjadi dapat terlihat di pengamatan, pernyataan tidak langsung dan pernyataan. Dari peran guru di atas terlihat bahwasannya, dalam kemandirian anak yang memerlukan peran guru ada pada rutinitas yaitu playground time danmasuk kelas terdapat peran guru yang lebih dominan sehingga membutuhkan peran guru yang lebih besar. Untuk lebih jelasnya maka, dari tabel berikut ini 
dapat dilihat jumlah atau presentase peran guru dari kemandirian:

Tabel 2. Tabel Peran Guru dalam Menanamkan Kemandirian Terdapat Pada Kesadaran Diri

\begin{tabular}{|c|c|c|c|c|c|c|}
\hline No & ASPEK & \multicolumn{5}{|c|}{ PERAN GURU } \\
\hline 1. & $\begin{array}{c}\text { Sosial } \\
\text { Emosional }\end{array}$ & Pengamatan & $\begin{array}{c}\text { Pernyataan } \\
\text { tidak } \\
\text { langsung }\end{array}$ & Pertanyaan & $\begin{array}{c}\text { Pernyataan } \\
\text { langsung }\end{array}$ & $\begin{array}{c}\text { Tindakan } \\
\text { Fisik }\end{array}$ \\
\hline & $\begin{array}{l}\text { Kesadaran Diri: } \\
\text { 1) mengikuti } \\
\text { aktivitas dalam } \\
\text { suatu kegiatan } \\
\text { besar }\end{array}$ & (3) (4) & $\begin{array}{l}\text { (2) (3) (5) } \\
\text { (7) }\end{array}$ & (2) & (2) & $\begin{array}{l}\text { (2) (3) } \\
\text { (6) }\end{array}$ \\
\hline & $\begin{array}{l}\text { 2) meniru apa } \\
\text { yang dilakukan } \\
\text { orang dewasa. }\end{array}$ & (1) & (5) & & (3) & $\begin{array}{l}\text { (1) (3) } \\
\text { (4) (6) }\end{array}$ \\
\hline & $\begin{array}{l}\text { 3) bereaksi } \\
\text { terhadap hal- } \\
\text { hal yang tidak } \\
\text { benar (marah } \\
\text { bila diganggu). }\end{array}$ & & & (2) & (2) (6) & (2) \\
\hline & $\begin{array}{l}\text { 4) mengatakan } \\
\text { perasaan secara } \\
\text { verbal. }\end{array}$ & & & (1) & (1) (4) & \\
\hline
\end{tabular}

Keterangan:

1. Kedatangan dan penyambutan siswa

2. Playground time

3. Masuk kelas

4. Circle time

5. Psikomotor time

6. Snack time

7. Pelepasan siswa untuk pulang

\section{Tanggung Jawab Diri}

Aspek kemandirian yaitu sosial emosional di dalam tanggung jawab diri yang terdapat dalam kegiatan yaitu mulai menghargai orang lain. Berkaitan dengan tanggung jawab diri yaitu yang terdapat pada kedatangan dan penyambutan siswa. Sedangkan peran guru yang terdapat yaitu ada pada tindakan fisik. Tindakan fisik dengan sentuhan antara tangan: Guru yaitu miss LC dan miss SI memberikan tangan untuk anak $\mathrm{R}$ salim dan anak menyambut tangan guru untuk bersaliman (6/11/2019: 08:30). Bersabar menunggu giliran, dimana didalam rutinitas terdapat playground time sesuai dengan peran guru yang meiliputi tindakan fisik, perihal: Anak $\mathrm{T}$ dan $\mathrm{A}$ dari toddler 1 dan 2 bersabar menunggu giliran tidak berusaha mendorong teman didepannya saat menaiki permainan (9/4/19: 08.45).

Mulai menunjukkan ekspresi menyesal ketika melakukan kesalahan, dimana didalam rutinitas terdapat playground time sesuai dengan peran guru yang meiliputi pernyataan langsung: Anak $\mathrm{C}$ dan $\mathrm{M}$ dari toddler 1 dan 2 mulai menunukkan ekspresi menyesal ketika melakukan kesalahan yaitu mengganggu temannya (9/4/19: 08.45). Bersabar menunggu giliran, dimana didalam rutinitas terdapat masuk kelas sesuai dengan peran guru yang meiliputi tindakan fisik: Anak-anak dari toddler 1 dan toddler 2 bersabar menunggu giliran dengan berbaris sesuai dengan barisan(9/4/19: 09.00).

Bersabar menunggu giliran, dimana didalam rutinitas terdapat circle time sesuai dengan peran guru yang meiliputi pertanyaan. Sebagai berikut: Miss UM dan SI bertanya kepada anak yaitu $\mathrm{H}$ dan $\mathrm{R}$ mengenai profesi dan kendaraan yang dipakai dan anak menyebutkan profesipekerjaan apa yang ia ketahui dan kendaraan apa yang digunakan (9/4/19: 09.30). Mulai menghargai orang lain, dimana di dalam rutinitas terdapat circle time sesuai dengan peran guru yang meiliputi halnya pernyataan langsung, sesuai dengan: Miss UM dan miss SI mengajarkan anak-anak toddler 1 dan 2 untuk mengucapkan terimakasih jika sudah dibantu oleh orang lain anak menunjukan dan mengucapkan terimakasih jika sudah dibantu oleh orang lain (9/4/19: 09.30).

Mulai menunjukkan ekspresi menyesal ketika melakukan kesalahan, dimana didalam rutinitas terdapat circle time sesuai dengan peran guru yang meiliputi pernyataan langsung, seperti dibawah ini: Miss UM dan miss SI dari toddler 1 dan 2 guru menegur anak yaitu $\mathrm{R}$ dan $\mathrm{R}$ yang tidak tertib dan jika sudah $3 \mathrm{x}$, maka akan dikeluarkan dari kelas dan anak menunjukkan ekspresi menyesal ketika melakukan kesalahan(9/4/19: 09.30). Mulai bisa melakukan buang air kecil tanpa bantuan, dimana didalam rutinitas terdapat psikomotor time sesuai dengan peran guru yang meiliputi pengamatan dan tindakan fisik. Sebagai mana pengamatan: Guru toddler 1 bernama miss UM beliau di damping asisten kelas yaitu miss TR menunggu anak buang air kecil tanpa bantuan (28/3/19: 10.00).

Tindakan fisik seperti anak dapat melakukan kegiatan fisik, berikut: Anak $\mathrm{R}$ mulai bisa melakukan buang air kecil tanpa bantuan (28/3/19: 10.00). Bersabar menunggu giliran, dimana didalam rutinitas terdapat psikomotor time sesuai dengan peran guru yang meiliputi pernyataan langsung: Guru UM dan TR memberitahu anak yaitu $\mathrm{R}$ untuk bersabar dalam mengantri dan anak bersabar menunggu giliran pada saat mengantri (28/3/19: 10.00). 
Bersabar menunggu giliran, dimana didalam rutinitas terdapat snack time sesuai dengan peran guru yang meiliputi pengamatan dengan: Miss UM dan Si mengamati anak-anak kelas toddler 1 dan 2 yang duduk rapih agar ditunjuk untuk mengambil bekal makanan di tas dan semua anak mencoba duduk dengan rapih agar ditunjuk untuk mengambil bekal makanan di tas (9/4/19: 10.30).

Mulai menunjukkan sikap toleran sehingga dapat bekerja dalam kelompok. dimana didalam rutinitas terdapat snack time sesuai dengan peran guru yang meiliputi pertanyaan dan tindakan fisik. Sedangkan pada peran guru pertanyaan seperti berikut: GuruUM dan Si bertanya kepada anak-anak kelas toddler 1 dan 2 siapa yang membawa sendok lebih untuk dipinjamkan kepada teman sebayanya (9/4/19: 10.30).

Tindakan fisik yang dilakukan antara anak didik kepada anak didik, seperti pada hal dibawah ini: Anak U meminjamkan sendok kepada temannya $\mathrm{R}$ yang tidak membawa sendok (9/4/19: 10.30). Mulai menghargai orang lain, dimana didalam rutinitas terdapat snack time sesuai dengan peran guru yang meiliputi pernyataan langsung. Pernyataan langsung yang menggambarkan: Guru UM dan TR berkata pada $\mathrm{R}$ untuk menawarkan makanan kepada orang lain dan anak menawarkan makanannya (9/4/19: 10.30). Mulai menunjukkan ekspresi menyesal ketika melakukan kesalahan, dimana didalam rutinitas terdapat snack time sesuai dengan peran guru yang meiliputi pertanyaan. Sedangkan pertanyaan dibawah ini menunjukkan: Miss UM dan Si bertanya siapa yang menumpahkan minuman (9/4/19: 10.30).

Tindakan fisik terjadi saat minuman tertumpah basah dan dilakukannya gerakan tangan pada anak: Anak $\mathrm{U}$ dan $\mathrm{R}$ menumpahkan minuman dan mengelapnya sendiri (9/4/19: 10.30). Mulai menghargai orang lain, dimana didalam rutinitas terdapat pelepasan siswa untuk pulang sesuai dengan peran guru yang meiliputi pernyataan langsung dan tindakan fisik. Selanjutnya saat pernyataan langsung: Guru kelas kelompok toddler 1 bernama miss UM beliau di damping asisten kelas yaitu miss TR mengucapkan salam perpisahan dan anak $\mathrm{S}$ menjawab salam (28/3/19: 11.00). Tindakan fisik antara guru dan anak didik, seperti kegiatan dibawa ini: Guru kelompok toddler 1 bernama miss UM juga asisten kelas yaitu miss TR mengantarkan anak untuk dijemput orangtua dan anak $\mathrm{S}$ menyalami guru (28/3/19: 11.00).

Dari uraian di atas dapat terlihat, bahwa aspek sosial emosional yang terdiri dalam tanggung jawab diri, yang meliputi mulai bisa melakukan buang air tanpa bantuan, yaitu hambatan yang terjadi dapat terlihat di pengamatan dan tindakan fisik. Selanjutnya meliputi mulai menunjukkan sikap toleran sehingga dapat bekerja dalam kelompok, yaitu hambatan yang terjadi dapat terlihat di pertanyaan dan tindakan fisik. Kemudian meliputi mulai menunjukkan ekspresi menyesal ketika melakukan kesalahan, yaitu hambatan yang terjadi dapat terlihat di pertanyaan dan tindakan fisik. mulai menghargai orang lain. Mulai menghargai orang lain meliputi pernyataan langsung dan tindakan fisik. Dari peran guru di atas terlihat bahwasannya, dalam kemandirian anak yang memerlukan peran guru ada pada rutinitas yaitu psikomotor time, snack time dan pelepasan siswa untuk pulangterdapat peran guru yang lebih dominan sehingga membutuhkan peran guru yang lebih besar. Untuk lebih jelasnya maka, dari tabel berikut ini dapat dilihat jumlah atau presentase peran guru dari kemandirian:

Tabel 3. Tabel Peran Guru dalam Menanamkan Kemandirian Terdapat Pada Tanggung Jawab Diri

\begin{tabular}{|c|c|c|c|c|c|c|}
\hline $\mathbf{N}$ & ASPEK & & & RAN GUR & & \\
\hline & $\begin{array}{c}\text { Sosial } \\
\text { Emosional }\end{array}$ & Pengamatan & $\begin{array}{c}\text { Pernyataan } \\
\text { tidak } \\
\text { langsung }\end{array}$ & Pertanyaan & $\begin{array}{c}\text { Pernyataan } \\
\text { langsung }\end{array}$ & $\begin{array}{c}\text { Tindakan } \\
\text { Fisik }\end{array}$ \\
\hline & $\begin{array}{l}\text { Tanggung jawab } \\
\text { diri: }\end{array}$ & & & & & \\
\hline & $\begin{array}{l}\text { 1) mulai bisa } \\
\text { melakukan } \\
\text { buang air tanpa } \\
\text { bantuan. }\end{array}$ & (5) & & & & (5) \\
\hline & $\begin{array}{l}\text { 2) bersabar } \\
\text { menunggu } \\
\text { giliran. }\end{array}$ & (6) & & (4) (3) & (5) & $\begin{array}{l}\text { (2) (3) } \\
\text { (7) }\end{array}$ \\
\hline & $\begin{array}{ll}\text { 3) } & \text { mulai } \\
\text { menunjukkan } \\
\text { sikap toleran } \\
\text { sehingga dapat } \\
\text { bekerija dalam } \\
\text { kelompok. }\end{array}$ & & & (6) & & (6) \\
\hline & $\begin{array}{l}\text { 4) mulai } \\
\text { menghargai } \\
\text { orang lain. }\end{array}$ & & & & (4) (6) (7) & (1) (7) \\
\hline & $\begin{array}{l}\text { 5) mulai } \\
\text { menunjukkan } \\
\text { ekspresi } \\
\text { menyesal ketika } \\
\text { melakukan } \\
\text { kesalahan. }\end{array}$ & & & (6) & (2) (4) & (6) \\
\hline
\end{tabular}

\section{Perilaku Prososial}

Aspek kemandirian yaitu sosial emosional di dalam perilaku prososial yang terdapat dalam kegiatan yaitu meminjam dan meminjamkan mainan. Berkaitan dengan perilaku prososial yaitu yang terdapat pada playground time. 
Sedangkan peran guru yang terdapat yaitu ada pada pertanyaan dan tindakan fisik. Pada pertanyaan antara lain sebagai berikut: Anak bertanya pada temannya untuk meminjam mainan yaitu A dan $\mathrm{J}$ dari Toddler 2 (6/11/2019: 08:30). Sedangkan peran guru di dalam tindakan fisik terdapat, yaitu: Anak meminjamkan mainan pada temannya yaitu anak A dan anak J dari Toddler 2 (6/11/2019: 08:30).

Dari uraian di atas dapat terlihat, bahwa aspek sosial emosional yang terdiri dalam kesadaran diri, yang meliputi salah satunya meminjam dan meminjamkan mainan. Dari peran guru di atas terlihat bahwasannya, dalam kemandirian anak yang memerlukan peran guru ada pada rutinitas yaitu playground time terdapat peran guru yang lebih dominan sehingga membutuhkan peran guru yang lebih besar. Untuk lebih jelasnya maka, dari tabel berikut ini dapat dilihat jumlah atau presentase peran guru dari kemandirian:

Tabel 4. Tabel Peran Guru dalam Menanamkan Kemandirian Terdapat Pada Perilaku Prososial

\begin{tabular}{|c|c|c|c|c|c|c|}
\hline \multirow{2}{*}{$\begin{array}{l}\mathbf{N} \\
\mathbf{0} \\
1 .\end{array}$} & \multirow{2}{*}{$\begin{array}{c}\text { ASPEK } \\
\text { KEMANDIRIAN } \\
\text { Sosial } \\
\text { Emosional }\end{array}$} & \multicolumn{5}{|c|}{ PERAN GURU } \\
\hline & & Pengamatan & $\begin{array}{c}\text { Pernyataan } \\
\text { tidak } \\
\text { langsung }\end{array}$ & Pertanyaan & $\begin{array}{c}\text { Pernyataan } \\
\text { langsung }\end{array}$ & $\begin{array}{c}\text { Tindakan } \\
\text { Fisik }\end{array}$ \\
\hline & Perilaku Prososial: & & & & & \\
\hline & $\begin{array}{l}\text { 1) membangun } \\
\text { kerjasama. }\end{array}$ & & & & & \\
\hline & $\begin{array}{l}\text { 2) memahami } \\
\text { adanya perbedaan } \\
\text { perasaan (teman } \\
\text { takut, saya tidak). }\end{array}$ & & & & & \\
\hline & $\begin{array}{l}\text { 3) meminjam dan } \\
\text { meminjamkan } \\
\text { mainan. }\end{array}$ & & & (2) & & (2) \\
\hline
\end{tabular}

Fisik

Aspek kemandirian yaitu motorik kasar di dalam fisik yang terdapat dalam kegiatan yaitu membersihkan kotoran (ingus). Berkaitan dengan fisik yaitu yang terdapat pada psikomotor time. Sedangkan peran yang terdapat ada pada pengamatan, pernyataan langsung, dan tindakan fisik. Pada Pengamatan sendiri, seperti: Miss toddler 1 bernama miss UM beliau di damping asisten kelas yaitu miss TR memperhatikan anak saat membuang kotoran (ingus) dan anak yaitu $\mathrm{H}$ mengamati arahan guru (28/3/19: 10.00).

Pernyataan langsung yang diucapkan guru langsung kepada anak mengenai hal ini: Guru yaitu miss UM dan miss TR memberitahu anak yaitu $\mathrm{H}$ untuk membuang kotoran (ingus) dan anak yaitu $\mathrm{H}$ membersihkan kotoran (ingus) (28/3/19: 10.00). Tindakan fisik yaitu guru mencontohkan gerakan mana yang harus dimulai terlebih dahulu kepada anak, mengenai: Miss UM dan miss TR mencontohkan anak yaitu $\mathrm{H}$ untuk membuang kotoran (ingus) dengan cara bergantian antara lubang hidung kanan dan kiri dan anak yaitu $\mathrm{H}$ membersihkan kotoran (ingus) secara bergantian (28/3/19: 10.00).

Menggosok gigi, dimana didalam rutinitas terdapat psikomotor time sesuai dengan peran guru yang meiliputi pernyataan tidak langsung, pernyataan langsung dan tindakan fisik.Pada pernyataan tidak langsung: Miss UM dan miss TR sebagai guru kelas dan asisten guru kelas mengingatkan anak yaitu $\mathrm{H}$ untuk menungkan odol pada sikat gigi dan anak mencoba menungkan odol pada sikat gigi (28/3/19: 10.00). Pernyataan langsung antara guru memberi arahan menggosok gigi kepada anak untuk mencoba menggosok gigi sendiri: Selanjutnya UM dan miss TR memberi arahan menggosok gigi kepada anak yaitu $\mathrm{H}$ mulai mencoba menggosok gigi sendiri sesuai yang diajarkan (28/3/19: 10.00).

Tindakan fisik dengan guru yaitu memberikan arahan bagaimana, seperti: Guru yaitu UM dan miss TR memberi contoh bagaimana cara menggosok gigi yang tepat kepada anak yaitu $\mathrm{H}$ mulai mencoba menggosok gigi sendiri sesuai yang dicontohkan oleh guru toddler 1 (28/3/19: 10.00). Mengelap tangan dan muka sendiri, dimana didalam rutinitas terdapat psikomotor time sesuai dengan peranan guru yang meiliputi pengamatan, pernyataan langsung, dan tindakan fisik. Sedangkan pada pengamatan terdapat: Guru kelas miss UM juga miss TR memperhatikan anak untuk mengelap tangan dan muka sendiri dan anak yaitu $\mathrm{H}$ mengamati (28/3/19: 10.00).

Pernyataan langsung guru berusaha mengingatkan anak agar mengelap tangan dan muka sendiri, seperti: Kemudian guru UM dan TR mengingatkan anak $\mathrm{H}$ untuk mengelap tangan dan muka sendiri dengan tidak terburuburu dan anak mengelap tangan dan muka sendiri (28/3/19: 10.00). Tindakan fisik yang dilakukan seperti terkait dengan tindakan di bawah ini: Terjadinya peranan fisik pada saat guru yaitu miss MU dan miss TR sebagai asisten memberikan contoh untuk anak yaitu $\mathrm{H}$ 
agar mengelap tangan dan muka sendiri dan $\mathrm{H}$ mengelap tangan juga muka sendiri (28/3/19: 10.00).

Dari uraian di atas dapat terlihat, bahwa aspek sosial emosional yang terdiri dalam motorik kasar, yang meliputi yaitu membersihkan kotoran (ingus) yaitu hambatan yang terjadi dapat terlihat di pengamatan, pernyataan langsung juga pada tindakan fisik. Meliputi menggosok gigi yaitu hambatan yang terjadi dapat terlihat di pernyataan tidak langsung, pernyataan langsung dan tindakan fisik. Meliputi mengelap tangan dan muka sendiri yaitu hambatan yang terjadi dapat terlihat di pengamatan, pernyataan langsung juga pada tindakan fisik. Dari peran guru di atas terlihat bahwasannya, dalam kemandirian anak yang memerlukan peran guru ada pada rutinitas yaitu psikomotor time lebih dominan sehingga membutuhkan peran guru yang lebih besar. Untuk lebih jelasnya maka, dari tabel berikut ini dapat dilihat jumlah atau presentase peran guru dari kemandirian:

Tabel 5. Tabel Peran Guru dalam Menanamkan Kemandirian Terdapat Pada Motorik Kasar

\begin{tabular}{|c|c|c|c|c|c|c|}
\hline \multirow{2}{*}{\begin{tabular}{|l|} 
No \\
1.
\end{tabular}} & \multirow{2}{*}{$\begin{array}{c}\text { ASPEK } \\
\text { KEMANDIRIAN } \\
\text { Fisik }\end{array}$} & \multicolumn{5}{|c|}{ PERAN GURU } \\
\hline & & Pengamatan & $\begin{array}{c}\text { Pernyataan } \\
\text { tidak } \\
\text { langsung }\end{array}$ & Pertanyaan & $\begin{array}{c}\text { Pernyataan } \\
\text { langsung }\end{array}$ & $\begin{array}{c}\text { Tindakan } \\
\text { Fisik }\end{array}$ \\
\hline & Motorik kasar: & \multirow[b]{2}{*}{ (5) } & & & \multirow[b]{2}{*}{ (5) } & \multirow[b]{2}{*}{ (5) } \\
\hline & $\begin{array}{l}\text { 1) membersihkan } \\
\text { kotoran (ingus). }\end{array}$ & & & & & \\
\hline & $\begin{array}{l}\text { 2) menggosok } \\
\text { gigi. }\end{array}$ & & (5) & & (5) & (5) \\
\hline & $\begin{array}{l}\text { 3) mengelap } \\
\text { tangan dan } \\
\text { muka sendiri. }\end{array}$ & (5) & & & (5) & (5) \\
\hline
\end{tabular}

Dari hasil penelitian peran guru yang dilakukan diketahui, agar dapat menumbuhkan kemandirian anak salah satunya dengan guru bertanya pada anak secara langsung, di ingatkan dan memberi contoh, seperti memberikan pemahaman yang positif, mendidik anak terbiasa rapih. Selanjutnya dibuat pembiasaan pada anak, bisa berupa aturan-aturan yang biasanya telah di terapkan, maka anak akan terbiasa karena dilakukan prosesnya itu setiap hari. Bisa juga dengan memberikan permainan yang sesuai, memberikan pilihan kepada anak, membiasakan anak berperilaku sesuai tata krama dan memotivasi anak untuk tidak malasmalasan.

Peran guru yang terkait dengan penanaman kemandirian anak, ada lima jurus kontinum dan bahasa terstruktur yang bisa dijadikan acuan dalam buku yang ditulis oleh Massardi (2012) yang dapat digunakan para pendidik pada anakanak jenjang TK, PAUD, dan KB meliputi: Visually Looking On (pengamatan) di sini guru melakukan pengamatan terhadap seluruh situasi yang terjadi di dalam sentra, Non Direct Statement (pernyataan tidak langsung) jurus ini adalah pernyataan tidak langsung yang disampaikan guru kepada anak didiknya, Question (pertanyaan) berkomunikasi dengan anak menggunakan pertanyaan-pertanyaan langsung, Directive statement (pernyataan langsung) guru memberikan pernyataan langsung kepada anak didiknya yang sedang mengalami konflik, Physical Intervention (tindakan fisik) guru langsung melerai keduanya secara fisik dan memberi contoh bagaimana berkomunikasi dengan teman secara benar dan sopan.

Dari hasil penelitian dilihat dari rutinitas seharihari, adanya peran guru untuk menanamkan kemandirian pada anak melalui berbagai hal yang dilakukan. Berupa peran guru yang terlihat didalam rutinitas paling dominan dalam menanamkan kemandirian dan hambatan di dalam rutinitas yang dilakukan guru dalam menanamkan kemandirian. Sebagai ringkasan dan pemahaman maka, disajikan tabel peran guru dalam ini semua. Berikut ini dapat dilihat jumlah, total atau presentase peran guru dari kemandirian:

Tabel 6. Tabel Hasil Penelitian Peran Guru dalam Menanamkan Kemandirian

\begin{tabular}{|c|c|c|c|c|c|c|c|}
\hline $\mathrm{N}$ & ASPEK & & & PERAN GUR & & & \\
\hline 1. & $\begin{array}{c}\text { Sosial } \\
\text { Emosional }\end{array}$ & Pengamatan & $\begin{array}{c}\text { Pernyataan } \\
\text { tidak } \\
\text { langsung }\end{array}$ & Pertanyaan & $\begin{array}{c}\text { Pernyataan } \\
\text { langsung }\end{array}$ & $\begin{array}{c}\text { Tindakan } \\
\text { Fisik }\end{array}$ & Jumlah \\
\hline & 1) Kesadaran Diri & (3) (4) (1) & $\begin{array}{c}\text { (2) (3) (5) } \\
\text { (7) (5) }\end{array}$ & (2) (2) (1) & $\begin{array}{l}\text { (2) (3) (2) } \\
\text { (6) (1) (4) }\end{array}$ & $\begin{array}{l}\text { (2) (3) (6) } \\
\text { (1) (3) (4) } \\
\text { (6) (2) }\end{array}$ & 80 \\
\hline & $\begin{array}{l}\text { 2) Tanggung } \\
\text { jawab diri }\end{array}$ & (5) (6) & & $\begin{array}{l}\text { (4) (3) (6) } \\
\text { (6) }\end{array}$ & $\begin{array}{l}\text { (5) (4) (6) } \\
\text { (7) (2) (4) }\end{array}$ & $\begin{array}{c}(5)(2)(3) \\
(7)(6)(1) \\
\text { (7) (6) }\end{array}$ & 95 \\
\hline & $\begin{array}{l}\text { 3) Perilaku } \\
\text { Prososial }\end{array}$ & & & (2) & & (2) & 4 \\
\hline 2. & Fisik & & & & & & \\
\hline & 4) Motorik kasar & (5) (5) & (5) & & (5) (5) (5) & (5) (5) (5) & 45 \\
\hline & Total & & & & & & 222 \\
\hline
\end{tabular}

Penjelasan dari hasil tabel penelitian peran guru dalam menamkan kemandirian di atas, dilihat dari aspek kemandirian yang ada pada aspek sosial emosional dan aspek fisik. Didalam aspek sosial emosional terdapat STPPA (Standar Tingkat Pencapaian Perkembangan Anak Usia 3-4 Tahun) yang terdiri dari 
kesadaran diri, tanggung jawab diri, dan perilaku prososial. Selanjutnya didalam aspek fisik yang terdapat pada STPPA (Standar Tingkat Pencapaian Perkembangan Anak Usia 3-4 Tahun) yang terdiri dari yaitu, motorik kasar.

Berdasarkan hasil penelitian di atas yaitu yang ada pada peran guru terlihat dominan lebih besar ada pada kesadaran diri dibandingkan tanggung jawab diri, motorik kasar dan perilaku prososial. Pertama kesadaran diri dari keseluruhan yaitu, yang ada pada pengamatan hingga tindakan fisik. Terdapat rutinitas kedatangan dan penyambutan siswa sebanyak 4 kali, yang ada pada peran guru meliputi pengamatan, pertanyaan, pernyataan langsung dan tindakan fisik, playground time sebanyak 7 kali,yang ada pada peran guru meliputi pernyataan tidak langsung, pertanyaan, pernyataan langsung dan tindakan fiik, masuk kelas sebanyak 5 kali, yang ada pada peran guru meliputi pengamatan, pernyataan tidak langsung, pernyataan langsung dan tindakan fisik, circle time sebanyak 3 kali, yang terdapat pada peran guru meliputi pengamatan, pernyataan langsung dan tindakan fisik, psikomotor time sebanyak 2 kali, yang terdapat pada peran guru meliputi pernyataan tidak langsung, snack time sebanyak 3 kali, yang terdapat pada peran guru meliputi pernyataan langsung dan tindakan fisik, dan pelepasan siswa untuk pulang sebanyak 1 kali, yang terdapat pada peran guru yang meliputi pernyataan tidak langsung. Selanjutnya dari keseluruhan pada rutinitas yang dominan lebih besar terlihat di playground time. Maka, yang memerlukan peran guru ada pada pernyataan langsung dan tindakan fisik.

Kedua peran guru di dalam tanggung jawab diri dari keseluruhan yaitu, dilihat dari hasil peran guru yang ada pada pengamatan, pertanyaan, pernyataan langsung dan tindakan fisik. Terdapat rutinitas kedatangan dan penyambutan siswa sebanyak 1 kali, peran guru yang terdapat ada pada tindakan fisik, playground time sebanyak 2 kali, peran guru yang terdapat ada pada pernyataan langsung dan tindakan fisik, masuk kelas sebanyak 2 kali,, peran guru yang terlihat ada pada pertanyaan dan tindakan fisik, circle time sebanyak 2 kali, terdpat peran guru yang meliputi pertanyaan, dan pernyataan langsung, psikomotor time sebanyak 3 kali, peran guru yang terlihat ada pada pengamatan, pernyataan langsung dan tindakan fisik, snack time sebanyak $2 \mathrm{kali}$, peran guru yang terlihat ada pada pengamatan, pertanyaan, pernyataan langsung dan tindakan fisik, dan pelepasan siswa untuk pulang sebanyak 3 kali, peran guru yang ada meliputi pada pernyataan langsung dan tindakan fisik. Selanjutnya dari keseluruhan pada rutinitas yang dominan lebih besar terlihat seimbang pada rutinitas yaitu, masuk kelas dan psikomotor time. Maka, yang memerlukan peran guru ada pada pernyataan langsung dan tindakan fisik.

Ketiga peran guru di dalam fisik yaitu motorik kasar dari keseluruhan yaitu, dilihat dari hasil peran guru yang ada pada pengamatan, pernyataan tidak langsung, pernyataan langsung dan tindakan fisik. Terdapat rutinitas psikomotor time sebanyak 9 kali, yang ada pada pengamatan berjumlah 2 kali, pernyataan tidak langsung sebanyak 1 kali, pernyataan langsung sebanyak 3 kali, dan tidakan fisik sebanyak 3 kali. Selanjutnya dari keseluruhan pada rutinitas yang dominan lebih besar terlihat yaitu, pada psikomotor time. Selanjutnya peran guru yang dominan lebih besar terlihat di pertanyaan dan tindakan fisik. Maka, yang memerlukan peran guru ada pernyataan langsung dan tindakan fisik.

Keempat peran guru di dalam kesadaran diri yaitu perilaku prososial dari keseluruhan yaitu, dilihat dari hasil peran guru yang ada pada pertanyaan dan tindakan fisik. Selanjutnya dari keseluruhan pada rutinitas yang dominan lebih besar yaitu, ada pada playground time. yang terdapat di pertanyaan dan tindakan fisik. Maka, yang memerlukan peran guru ada pada pertanyaan dan tindakan fisik.

Dari hasil perbandingan antara peran guru di dalam kemandirian anak yang berkaitan dengan aspek sosial emosional dan aspek fisik, maka, di dalam aspek yaitu sosial emosional khususnya di kesadaran diri dan tanggung jawab diri anak perlu di adakan ruang dan waktu untuk menumbuhkan kesadaran dirinya. Namun dalam aspek fisik yaitu motorik kasar kurang memerlukan adanya peran guru, begitu juga dengan aspek sosial emosional yang terdapat di perilaku prososial. 


\section{Hambatan dalam Penanaman Kemandirian Pada Anak}

Dari hasil penelitian hambatan yang dialami guru, ditemukan dalam penanaman kemandirian anak berupa permasalahan dalam diri anak sendiri yang berasal dari faktor internal. Permasalahan yang dialami guru, terlihat pada saat anak melakukan kegiatan harus berdasarkan perintah atau berupa arahan dari guru terlebih dahulu, tanpa adanya kesadaran diri dalam diri anak, seperti pada saat masuk kelas guru terlebih dahulu mengingatkan anak untuk mengenakan kedua pasang kaos kaki dan sepatu, juga pada saat menyeka air tumpah dengan menggunakan lap. Permasalahan yang selanjutnya terlihat pada saat anak melakukan kegiatan tanpa adanya tanggung jawab diri dalam diri anak, seperti harus selalu dibimbing, saat anak menaruh kembali botol minuman pada tempatnya semula, anak akan menaruh jika ada perintah dari guru.

Berdasarkan hambatan dari hasil penelitian pada kesadaran diri dapat terlihat, kemandirian dari aspek sosial emosional yang terdiri dari kesadaran diri, yang meliputi mengikuti aktivitas dalam suatu kegiatan besar pada saat rutinitas playground time, yaitu hambatan yang terjadi dapat terlihat di pernyataan tidak langsung berupa (guru berkata bermain tidak saling mendorong teman), pertanyaan (guru bertanya ada masalah apa yang membuat anak menangis), pernyataan langsung(guru berkata bahwa anak yang baik adalah saat saling menyayangi), dan tindakan fisik (guru merangkul kedua anak untuk saling bermaafan). Selanjutnya meliputi bereaksi terhadap hal-hal yang tidak benar (marah bila diganggu) pada rutinitas playground time, yaitu hambatan yang terjadi dapat terlihat di pertanyaan (guru bertanya ada masalah apa yang membuat anak menangis?), pernyataan langsung (guru berkata bahwa anak yang baik adalah saling menyayangi), dan tindakan fisik (guru merangkul kedua anak untuk saling bermaafan). Kemudian meliputi mengikuti aktivitas dalam suatu kegiatan besar pada rutinitas masuk kelas, yaitu hambatan yang terjadi dapat terlihat di pengamatan (guru mengamati anak mana yang belum membuat barisan), pernyataan tidak langsung (guru menyatakan pernyataan tidak langsung ayo berkumpul membuat barisan kereta menuju kelas) dan pernyataan (guru mencontohkan semuanya untuk memegang bahu teman didepannya). Dari hambatan di atas terlihat bahwasannya, dalam kemandirian anak yang memerlukan peran guru ada pada rutinitas yaitu playground time danmasuk kelas terdapat peran guru yang lebih dominan sehingga membutuhkan peran guru yang lebih besar.

Berdasarkan hambatan dari hasil penelitian pada tanggung jawab diri dapat terlihat, kemandirian dari aspek sosial emosional yang terdiri dari tanggung jawab diri, yang meliputi mulai bisa melakukan buang air tanpa bantuan pada rutinitas psikomotor time, yaitu hambatan yang terjadi dapat terlihat di pengamatan (guru menunggu anak buang air kecil tanpa bantuan). Selanjutnya meliputi mulai menunjukkan sikap toleran sehingga dapat bekerja dalam kelompok pada rutinitas snack time, yaitu hambatan yang terjadi dapat terlihat di pertanyaan (guru bertanya siapa yang membawa sendok lebih). Kemudian mulai menunjukkan ekspresi menyesal ketika melakukan kesalahan pada rutinitas snack time, yaitu hambatan yang terjadi dapat terlihat di pertanyaan (guru bertanya siapa yang menumpahkan air minuman). Mulai menghargai orang lain pada rutinitas pelepasan siswa untuk pulang, hambatan meliputi pernyataan langsung (guru mengucapkan salam perpisahan) dan tindakan fisik (guru mengantar anak untuk dijemput wali). Dari hambatan di atas terlihat bahwasannya, dalam kemandirian anak yang memerlukan peran guru ada pada rutinitas yaitu psikomotor time, snack time dan pelepasan siswa untuk pulangterdapat peran guru yang lebih dominan sehingga membutuhkan peran guru yang lebih besar.

Berdasarkan hambatan dari hasil penelitian yang terjadi pada fisik yaitu motorik kasar dapat terlihat, kemandirian dari aspek sosial emosional yang terdiri dalam motorik kasar, yang meliputi yaitu membersihkan kotoran (ingus) pada rutinitas psikomotor time, yaitu hambatan yang terjadi dapat terlihat di pengamatan (guru memperhatikan anak saat membuang kotoran (ingus), pernyataan langsung (guru memberitahu anak untuk membuang kotoran (ingus) juga pada tindakan fisik (guru memberitahu anak untuk membuang kotoran (ingus) dengan cara bergantian antara lubang hidung kanan dan kiri). Meliputi menggosok gigi pada rutinitas psikomotor time, yaitu hambatan yang terjadi dapat terlihat di pernyataan tidak langsung (guru mengingatkan 
anak untuk menungkan odol pada sikat gigi), pernyataan langsung (guru memberi arahan menggosok gigi) dan tindakan fisik (guru memberitahu anak cara memegang gosok gigi). Meliputi mengelap tangan dan muka sendiri pada rutinitas psikomotor time, yaitu hambatan yang terjadi dapat terlihat di pengamatan (guru memperhatikan anak untuk mengelap tangan dan muka sendiri), pernyataan langsung (guru mengingatkan anak untuk mengelap tangan dan muka sendiri dengan tidak terburu-buru) juga pada tindakan fisik (guru mencontohkan anak untuk mengelap tangan dan muka sendiri). Dari hambatan di atas terlihat bahwasan nya, dalam kemandirian anak yang memerlukan peran guru ada pada rutinitas yaitu psikomotor time lebih dominan sehingga membutuhkan peran guru yang lebih besar.

Berdasarkan hasil penelitian yang telah dikemukakan, perlu dianalisis untuk menjawab fokus masalah yaitu mengenai peran guru dalam menanamkan kemandirian anak melalui pembelajaran di First Rabbit Preschool and Day Care.

Permasalahan yang dialami guru, terlihat pada saat anak melakukan kegiatan harus berdasarkan perintah atau berupa arahan dari guru terlebih dahulu, tanpa adanya kesadaran diri dalam diri anak, seperti pada saat masuk kelas, guru terlebih dahulu mengingatkan anak untuk mengenakan kedua pasang kaos kaki dan sepatu, juga pada saat menyeka air tumpah dengan menggunakan lap. Berbeda dengan anak, anak tidak dapat dengan mudah mengemukakan perasaannya atau cenderung diam. Hal tersebut dijelaskan oleh Mashar (2011) bahwa kemampuan emosional anak merupakan sebuah keterampilan anak dalam mengemukakan kesadaran, pengaturan, dan pengelolaan perasaan yang terjadi dalam dirinya lebih cepat berubah dalam memberikan tindakan melalui sikap diri untuk mencapai kebahagiaan dirinya sendiri. Berdasarkan penjabaran tersebut dapat diartikan bahwa emosi anak tidaklah stabil.

Permasalahan yang selanjutnya terlihat pada saat anak melakukan kegiatan tanpa adanya tanggung jawab diri dalam diri anak, seperti harus selalu dibimbing, saat anak menaruh kembali botol minuman pada tempatnya semula, anak akan menaruh jika ada perintah dari guru. Menurut Yamin (2003), anak dikatakan mandiri apabila ia mampu mengambil keputusan untuk bertindak, memiliki tanggung jawab dan tidak bergantung pada orang lain, melainkan percaya pada dirinya sendiri. Bertanggung jawab menerima konsekuensi yang menyertai pilihannya pada saat anak usia dini mengambil keputusan atau pilihan, tentu ada konsekuensi yang melekat pada pilihannya. Anak yang mandiri akan bertanggung jawab atas keputusan yang diambilnya apa pun yang terjadi. Tentu saja bagi anak usia dini tanggung jawab tersebut dilakukan dalam taraf yang wajar. Berdasarkan penjabaran tersebut dapat diartikan bahwa tanggung jawab diri anak haruslah berada pada tahapan yang wajar pada batasan usia nya.

\section{SIMPULAN DAN SARAN}

Berdasarkan pembahasan pada sub fokus penelitian, maka dapat disimpulkan sebagai berikut: pertama, Penanaman kemandirian di sekolah first rabbit preschool and day care dapat tercapai melalui adanya peran guru yang telah dilaksanakan melalui kelima kontinum yang meliputi; Visually Looking On (pengamatan); Non Direct Statement (pernyataan tidak langsung); Question (pertanyaan); Directive statement (pernyataan langsung); serta Physical Intervention (tindakan fisik). Kelima peran tersebut muncul di dalam rutinitas kedatangan sampai dengan kepulangan, yang disampaikan dan dijalankan dengan konsisten. Selanjutnya peran guru yang ada pada kesadaran diri terlihat dominan lebih besar dibandingkan tanggung jawab diri, motorik kasar dan perilaku prososial.

Kedua, hambatan yang ditemukan dalam penanaman kemandirian pada anak, berupa permasalahan dalam diri anak sendiri yang berasal dari faktor internal. Permasalahan yang terlihat pada saat anak melakukan kegiatan harus berdasarkan perintah atau berupa arahan seperti harus selalu dibimbing oleh guru terlebih dahulu, tanpa adanya kesadaran diri dan tanggung jawab diri dalam diri anak.

Berdasarkan hasil penelitian, maka terdapat beberapa saran yang dapat dikemukakan dari hasil penelitian ini adalah sebagai berikut: pertama, hendaknya guru memberikan pemahaman yang positif, mendidik anak terbiasa rapih. Selanjutnya dibuat pembiasaan pada anak, bisa berupa aturan-aturan yang 
biasanya telah di terapkan, maka anak akan terbiasa karena dilakukan prosesnya itu setiap hari. Membiasakan anak berperilaku sesuai tata krama dan memotivasi anak untuk tidak malasmalasan.

Kedua, hendaknya guru memberikan motivasi pada anak untuk dapat melakukan kegiatan sederhana sendiri, serta mengatakan bahwa anak bisa melakukannya seperti teman-teman yang lainnya. Guru memberitahu bahwa tidak selamanya dapat berada di dekat anak membantu kesulitan anak.

\section{DAFTAR PUSTAKA}

Apley, G. (2001). Apley's system of orthopaedics and fractures. 8 edition. USA, Oxford University Press Inc.

Brewer, A.J. (2007). Introduction to early children education preschool trough prymary grades. Pearson: Allin And Bacon.

Dixie, G. (2007). Managing Your Classroom. New York. Continuum.

Emmer, E.T., \& Stough, L.M. (2001). Classroom management: A critical part of educational psychology, with implications for teacher education. Educational Psychologist, 36(2), 103-112.

Fadholi, M. (2011). Tingkat kemandirian anak usia prasekolah ditinjau dari pola asuh demokrasi. Skripsi. Surakarta: Universitas Muhammadiyah Surakarta.

Gray, et al. (2005). Lecture Notes Kardiologi edisi 4. Jakarta: Erlangga Medical Series.

Hidayat, A.A. (2008) Pengantar ilmu keperawatan anak. Cetakan ketiga. Jakarta: Salemba Medika.

Kee, J.L. (2007). Pedoman pemeriksaan laboratorium dan diagnostik. Edisi 6. Jakarta: EGC.

Mangunsong, Frieda. (2006). Mengembangkan sikap mandiri pada anak.

Massardi, S \& Yudhistira. (2012). Pendidikan Karakter dengan Metode Sentra. Jakarta: Esmass

Mashar, R. (2011). Emosi anak usia dini dan strategi pengembangan. Jakarta. Kencana.

Megan Northrup dalam Research Assistant, dan disunting oleh Stephen F. Duncan, Professor, School of Family Life, Brigham Young University, menjelaskan: (www.foreverfamilies.net/xml/articles/teac hing_children_self_regulatuon
Martinis, Y., Jamilah, S.S. (2013). Panduan PAUD pendidikan anak usia dini. Ciputat: Gaung Persada Press Group.

Nauta. (2007). Karakteristik kemandirian anak usia dini. Surabaya: Bumi Aksara

Nurfalah, Y. (2010). Panduan praktis melatih kemandirian anak usia dini. Bandung: PNFI Jayagiri

Novita, W. (2007). Serba-serbi anak. Jakarta: Gramedia

Peraturan Menteri Nomor 146 tahun 2013 tentang kurikulum 2013 pendidikan anak usia dini. Jakarta

Peraturan Menteri Pendidikan dan Kebudayaan (Permendikbud) Nomor 137 Tahun 2014 tentang standar nasional pendidikan anak usia dini.

Pontoh, W. (2013). Akuntansi konsep dan aplikasi. Jakarta: Halaman Moeka Publishing.

Pusat Kurikulum Balitbang Departemen Pendidikan Nasional. (2007). Standar isi pendidikan anak usia dini. Jakarta.

Rink, J.E. (2006). "Teaching physical education for learning" dalam Zacchopoulou, everidiki et all. Early Step Physical Education Curriculum. Roehampton University: United kingdom.

Sarafino, E.P., \& Smith, T.W. (2012). Health psychology: biopsychosocial interactions. John Wiley \& Sons Inc.

Satmoko, R.S. (2004). Psikologi tentang Penyesuaian dan Hubungan Kemanusiaan. Semarang: IKIP Semarang Press.

Utomo, S. (2005). Hubungan motivasi berprestasi, kemandirian dan prestasi belajar siswa kelas ii semester I Tahun Pelajaran 2004/2005 SMP N 2 Pabelan. Progdi BK UKSW.

Severe, S. (2002). Bagaimana bersikap pada anak agar anak pra sekolah anda bersijap baik. Jakarta: PT Gramedia Pustaka Utama.

Shalihah, M. (2010). Mengelola PAUD: mendidik budi pekerti anak usia dini bagi program PAUD, TK, Play Group, dan di Rumah. Bantul: Kreasi Wacana Offset.

Siedentop, D., Tannehill, D. (2000). Developing teaching skill in physical education. Mountain View CA: Mayfield.

Prasetyono, D.S. (2007). Membedah psikologi bermain anak. Jogjakarta: Think.

Wiyani. (2013). Bina karakter anak usia dini. Yogyakarta: Ar-ruzz Media.

Wiyani, N. A. (2014). Bina karakter anak usia dini: panduan orangtua dan guru dalam 
Jurnal AUDHI, Vol. 2, No. 2, Januari 2020

membentuk kemandirian dan kedisiplinan anak. Yogyakarta: Ar-ruzz Media.
Yudhistira, Massardi, SY. (2012). Pendidikan karakter dengan metode sentra. Bekasi: Media Pustaka Sentra. 